\title{
Testing Military Professionalism Construct: An Empirical Evidence From Indonesian Army (Case On Batallion Arhanud 2/ABW/2 Kostrad Malang)
}

\author{
Saekul Anwar ${ }^{1}$, Hafid Aditya Pradesa ${ }^{2}$, Fandi Ahmad ${ }^{3}$ \\ Polytechnic of STIA LAN Bandung ${ }^{123}$ \\ \{saekul.anwar@poltek.stialanbandung.ac.id ${ }^{1}$ \}
}

\begin{abstract}
Terms such as "profession", "professional", and "professionalization" are commonly used in everyday usage, but often poorly defined and ambiguous. In military organizations, the term "professionalism" is also commonly used. This study aims to examine the concept of military professionalism in the military unit in Malang City. Based on the literature review, both theoretically and empirically, the construct of military professionalism is developed in this study consisting of five dimensions: autonomy, maintenance of collegial standards, work ethics, professional commitment, and professional identification. By using quantitative methods, 150 Non-Commander Officers (CFO) of the Indonesian Army located in Malang, working in Batallion Arhanud 2/ABW/2 Kostrad Malang are taken as sample of this study. Second-Order Factor Analysis is used in this study to analyze the loading factor among indicators and dimensions. Results show that not all values of the military professionalism dimension have a significant value of loading factors. Two of five dimensions were found to have a factor weight value below the criteria and not significant that are (1) autonomy and (2) ethics from military professionalism, while the other three dimensions, namely maintenance of collegial standards, professional commitment, and professional identification, could reflect military professionalism well. Theoretical and empirical implications are discussed in this study.
\end{abstract}

Keywords : Military Professionalism, Factor Analysis, Indonesian Army.

\section{Introduction}

Due to a specific belief of the "military" as a unique organizational entity (NorheimMartinsen, 2016), the development of military organizations as institutions that are responsible for the national defense sector has its character. While others such as Holmberg \& Alvinius (2019) emphasized that military organization that stay on traditional characteristics that do not match the demands they put forward will experience failure to achieve their goals and even lose both external and internal legitimacy. It is important to note that the Indonesian Army force is a military entity insofar as the decision of using it as the military instrument of national power is a great deal among the country. 
Because of a heavy main duty to protect, defend and protect the integrity and sovereignty of the nation and state, it needs to be done with the power of weapons and means of war. But at the organizational level, a military organization commonly has three main factors that could form the organization: (1) people, (2) cooperation, and (3) certain goals, in where these three factors are interrelated and cannot be separated.

The way the Indonesian Army Forces are organized and trained and operated is determined by military doctrine. For all practical purposes, doctrine and force structure are intermixed. Based on Law No. 34 of 2004 concerning the Indonesian National Army, it has been explained that what is meant by Professional Soldiers are soldiers who are proficient in using military equipment, proficient in moving, and proficient in using combat equipment, and able to carry out tasks in a measurable manner and fulfill the values of accountability. For this reason, soldiers need to be trained in using weapons and other military equipment properly, trained in good tactical maneuvers, educated in science and technology properly, well-armed and equipped, and their welfare is guaranteed by the state so that they are expected to be proficient in combat. The statement mentioned in Law No. 34 of 2004 is still at the normative level so that conceptually it also needs to be studied further in the field.

The concept of professionalism has become one of the interesting studies in various sectors in organizations, including military organizations. As the most important element that represents the Armed Forces of the Republic of Indonesia, the Indonesian National Army Forces (TNI) is a strategic national institution that must have a sapta marga spirit and professionalism in carrying out every task as the main component of the national defense force (Kasenda et al., 2020; Ma'arif, 2015).

In its development, professionalism is very important and is often associated with individual performance in organizations(Evetts, 2013; Tanjung et al., 2020). Military professionalism is also associated with the democratic process inherent in the social order (Djuyandi, 2007), as well as amid the swift demands of the political situation that occurs (Kristiadi, 2014). As the goal of turning the Indonesian Armies into a professional military is not based on the wishes of the times or punishment for past mistakes (Tiara, 2013), because when military professionalism is born in the two things above, military professionalism seems to come suddenly. Military professionalism must be based on clear concepts and stages, Paterson (2019) argues that lacks a functional definition of military professionalism - a term that until recently was considered too vague and multifaceted to operationalize.

In developing an "ideal type" of military professionalism, the article explores, in particular, the insights of the literature on professionalism. Professionalism could be considered as a measure of how well individuals carry themselves at work, how they treat coworkers, and how they handle stressful situations (Freidson, 1999). Professionalism is a significant characteristic to demonstrate in every situation in daily work (Plant et al., 2010).

By showing professionalism, the individual can create new opportunities while a lack of professionalism can create obstacles to individuals' growth. In a military organization, content analysis had been used to support the argument about the concept of new professionalism in which its concern has emerged since world war II (Gates, 1985), while Harries-Jenkins (1990) argued that there are two major problem related to synthesis about military professionalism: (1) the evolution of armed forces as a professionalized occupational group and (2) military professionals are not autonomous fee-paid independent practitioners. This provide an opportunity to add more detail about the existing study of military professionalism by uncovering the factors that reflect it in facilitating the process of carrying out activities or work in an effective formal military organization. 
In several previous studies, military professionalism has become one of the important issues to be explored and studied. There are slightly different perspectives on how military professionalism can be interpreted by research experts or researchers in the military field. This study will explore and analyze the concept of military professionalism in a military organization. It is hoped that the results of this research can open up greater exploration space and theoretical clarity on the concept of military professionalism.

\section{Literature Review and Conceptual Framework Development}

Professionalism literally means having a profession and behaving according to the standards of that profession. The measure of professionalism in this context includes proving competence in the field and consistently behaving according to professional standards. These standards are often defined in codes of ethics or codes of conduct written by professional associations. Since a profession is a type of work, and the general activity of a job is work, the foundation of the professionalism model is work and the knowledge and skills required to do it (Freidson, 1999).

Professionalism is believed to be closely related to "professions", and it is rather hard to discuss one of them without involving the other. The terms professionalism, profession, and professional commitment have been used interchangeably and as often as one professionalism or professional commitment as stated by Sejjaaka \& Kaawaase (2014). In this study, the term "professional commitment and professionalism" is employed to describe the same concept. Professions generally possess structural attributes as their core. Moreover, a formal education, licensing certification, and continuing education, and professional development are required (Sejjaaka \& Kaawaase, 2014).

Hall (1968) figured out there is a critical relationship between professionalism and the attitudes and behaviors which drive how individuals think, what they believe, and how they behave towards their work or profession to include a sense of calling, job autonomy, and commitment to professional associations. This finding is the main principle to support Hall's (1968) theory which has been accepted until today.

To study the correlation between professionalism and bureaucratization, The professionalism model was separated into two components: structure and attitude. The Structure aspects include the full-time jobs creation, the training school's establishment, the formation of professional associations, and the establishment of a code of ethics (Hall, 1968). In Hall's (1968)study, it was stated that autonomy as an attribute of professionalism has both the aspect of structure and attitude. In analyzing the attitude component of professionalism, Hall developed a scale to measure five attitude attributes; professional organizations as the main reference, trust in public services, trust in self-regulation, a sense of calling, and autonomy.

Butler \& Budgell (2015) found several elements of the center of professionalism in the military, among others:

a. Expertise, or knowledge and skills which are required for the profession such as members of the military receive special training.

b. Legitimacy, or public trust in a profession that has authority and autonomy over certain areas. Thus, the military as a profession requires public trust to be a valid profession.

c. Jurisdiction, or job limitation specified to the profession. In the military field, the members often need solutions to situations that other professions regard it as not.

d. Identity, namely self-concept consisting of beliefs, attributes, values, motives, and experiences.

e. Culture is a set of shared beliefs and values within an organization. 
To develop and maintain military professionalism, discipline, socialization, and leadership also have important roles. Discipline is a way to maintain high military standards as a profession (Butler \& Budgell, 2015). Discipline includes the obligation to dress, behave, and practice, which helps control behavior through cues about what is acceptable or not, a sense of shared identity, and group structure and relationships.

Professionalism is a term that is difficult to define because of its subjective nature (HarriesJenkins, 1990; Haywood-Farmer \& Stuart, 1990). An important work by Hall (1968) has become the initial foundation of the concept of professionalism, and to this day serves as a defining standard that is widely used in the study and research of professionalism. Hall (1968) defines the attributes of professionalism and characterizes them into two major groups, namely structure, and attitude.

Structure refers to the composition of the profession and the requirements placed on the profession by the governing body or management of a profession. As the status of the military as a profession had been taken without a doubt (Harries-Jenkins, 1990), the structuralfunctionalist model of the ideal-type of the military profession had been identified as a basic construct to develop military professionalism. To measure professionalism in the military organization, the scale was developed in several phases. As previously stated in the literature review, the professionalism concept and measurement were reviewed, and those items were generated. In this study, a conceptual framework developed is seen in Figure 1. In addition, the conceptual framework becomes the basis for developing research instruments by taking into account the indicators that reflect each dimension construct of the military professionalism variable.

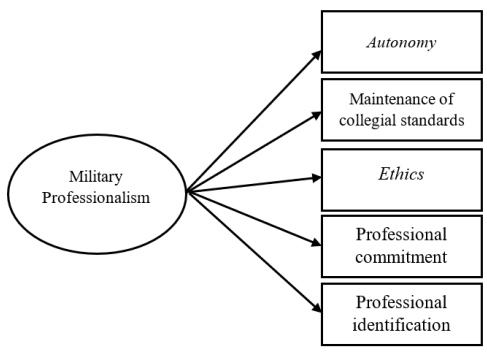

Fig 1. Conceptual Framework

\section{Method}

This study employed a cross-sectional quantitative research design, involving about 150 Non-Commander Officers (CFO) of the Indonesian Army who work in Batallion Arhanud 2/ABW/2 Kostrad Malang. The sample frame developed in this study used a non-probability sampling approach or was taken non-randomly with direct implementation using an online questionnaire and carried out by fulfilling health protocols during the pandemic.

The study was conducted using a questionnaire filled out online by respondents who participated in the study. A Likert scale was used in this study with a 1 (strongly disagree) to 5 (strongly agree) value. The questionnaire is a self-report measure and subject to concerns about the accuracy of self-assessment. The use of online research instruments and distribution during pandemic conditions provides another impression in the research process carried out. 
Table 1. Operationalization of the Concept of Military Professionalism

\begin{tabular}{|c|c|c|}
\hline Variable & Dimension & Indicators \\
\hline \multirow{15}{*}{$\begin{array}{c}\text { Military } \\
\text { Professionalism }\end{array}$} & \multirow{3}{*}{ Autonomy } & Make own decisions about what to do at work \\
\hline & & Organizations provide opportunities to get work done \\
\hline & & $\begin{array}{l}\text { Regularly attend professional meetings at the local } \\
\text { level }\end{array}$ \\
\hline & \multirow{3}{*}{$\begin{array}{c}\text { Maintenance } \\
\text { of collegial } \\
\text { standards }\end{array}$} & $\begin{array}{l}\text { Regularly develop knowledge by reading literature } \\
\text { related to work }\end{array}$ \\
\hline & & Know the standard of value in doing work \\
\hline & & Have a good idea of each other's competence \\
\hline & \multirow{3}{*}{ Work Ethic } & Do the job by upholding the basics of ethics \\
\hline & & Carrying out the profession with full of integrity \\
\hline & & $\begin{array}{l}\text { Carrying out the profession based on the value of } \\
\text { honesty }\end{array}$ \\
\hline & \multirow{3}{*}{$\begin{array}{l}\text { Professional } \\
\text { Commitment }\end{array}$} & have a big responsibility to get the job done \\
\hline & & have a high dedication as a non-commissioned soldier \\
\hline & & uphold the honor as a non-commissioned soldier \\
\hline & \multirow{3}{*}{$\begin{array}{c}\text { Professional } \\
\text { identification }\end{array}$} & $\begin{array}{l}\text { the profession as a soldier is very important for the } \\
\text { organization }\end{array}$ \\
\hline & & maintain a good level of warrior idealism \\
\hline & & communicate with other military units regarding work \\
\hline
\end{tabular}

Source : Adapted from Harries-Jenkins, (1990).

The data that has been collected is then analyzed using two-stage confirmatory factor analysis. This two-stage confirmatory analysis technique is considered the most appropriate data analysis tool for this study, namely to confirm the military professionalism model developed and tested in military organizations for this research. Each indicator in each dimension will be tested for the significance and factor weight of the indicators on the dimensions, as well as from the dimensions of the military professionalism variable.

The factor analysis used in this study considered the military professionalism model without dependent and independent variables. Yet, only dimensions and indicators for each were used. Factor analysis was carried out on primary data through questionnaires with primary data quantification in the form of perceptions of the Likert scale and using the weighted average as statistical data to be processed. Factor analysis did not classify the independent and dependent variables but looks for interdependent correlation among variables to identify the dimensions or factors that can formulate the construction of military professionalism.

\section{Result and Discussion}

Table 2. Reliability, Mean, and Factor Weight Value

\begin{tabular}{|c|c|c|c|}
\hline Construct & Indicator & Mean & $\begin{array}{l}\text { Loading } \\
\text { Factor }\end{array}$ \\
\hline \multirow{3}{*}{$\begin{array}{l}\text { Autonomy } \\
\alpha=0.871\end{array}$} & Make own decisions about what to do at work & 3.81 & .907 \\
\hline & $\begin{array}{l}\text { Organizations provide opportunities to get work } \\
\text { done }\end{array}$ & 3.85 & .901 \\
\hline & $\begin{array}{l}\text { Regularly attend professional meetings at the } \\
\text { local level }\end{array}$ & 3.89 & .867 \\
\hline
\end{tabular}




\begin{tabular}{|c|c|c|c|}
\hline Construct & Indicator & Mean & $\begin{array}{l}\text { Loading } \\
\text { Factor }\end{array}$ \\
\hline \multirow{3}{*}{$\begin{array}{c}\text { Maintenance } \\
\text { of collegial } \\
\text { standards } \\
\alpha=0.764\end{array}$} & $\begin{array}{l}\text { Regularly develop knowledge by reading } \\
\text { literature related to work }\end{array}$ & 3.83 & .749 \\
\hline & Know the standard of value in doing work & 4.10 & .850 \\
\hline & Have a good idea of each other's competence & 4.14 & .896 \\
\hline \multirow{3}{*}{$\begin{array}{l}\text { Work Ethic } \\
\alpha=0.728\end{array}$} & Do the job by upholding the basics of ethics & 3.84 & .857 \\
\hline & Carrying out the profession with full of integrity & 4.10 & .730 \\
\hline & $\begin{array}{l}\text { Carrying out the profession based on the value } \\
\text { of honesty }\end{array}$ & 3.69 & .834 \\
\hline \multirow{3}{*}{$\begin{array}{c}\text { Professional } \\
\text { Commitment } \\
\alpha=0.815\end{array}$} & have a big responsibility to get the job done & 3.93 & .813 \\
\hline & $\begin{array}{l}\text { have a high dedication as a non-commissioned } \\
\text { soldier }\end{array}$ & 4.08 & .913 \\
\hline & uphold the honor as a non-commissioned soldier & 4.22 & .838 \\
\hline \multirow[t]{3}{*}{$\begin{array}{l}\text { Professional } \\
\text { identification }\end{array}$} & $\begin{array}{l}\text { the profession as a soldier is very important for } \\
\text { the organization }\end{array}$ & 4.00 & .693 \\
\hline & maintain a good level of warrior idealism & 4.15 & .883 \\
\hline & $\begin{array}{l}\text { communicate with other military units regarding } \\
\text { work }\end{array}$ & 4.09 & .824 \\
\hline
\end{tabular}

Source: The data processed (2021).

The internal consistency of the factors proposed was tested by Cronbach's alpha $(\alpha)$. The results indicate that the values of all factors are $\alpha=0.7$. Therefore, the standard threshold for good internal consistency has been met. This indicates that the factors formed coherent the subscales. Based on the results of the confirmation factor analysis and the mean value, several important findings can be described as follows:

The dimension of autonomy tends to be reflected by the indicator of "make own decisions about what to do at work." The factor weight value for each indicator on the autonomy dimension ranges between $0.867-0.907$. All of the factors measured in this dimension have met the criteria for significance. Meanwhile, the most important thing that is perceived by the Non-Commander Officer (Bintara) respondents in Indonesian Army units is to "regularly attend professional meetings at the local level". The indicator value on the autonomy dimension ranges from 3.81 to 3.89 , with an average value of 3.85 . The mean value shows the perception of the Non-Commander Officer that the autonomy aspect of military professionalism can be categorized as good.

The dimension of maintenance of collegial standards tends to be reflected by the indicator of "have a good idea of each other's competence" for Non-Commander Officers. The value of the factor weights for each indicator in the maintenance of collegial standards dimension ranges from $0.749-0.896$. Meanwhile, the most important thing that is considered the most important by respondents is still in the same indicators. The indicator value on the dimension of maintenance of collegial standards ranges from 3.83 to 4.14, with an average value of 4.022 . The mean value indicates the dimension of maintenance of collegial standards in military professionalism can be categorized as good.

The dimension of work ethics tends to be reflected by indicators of "do the job by upholding the basics of ethics". The factor weight value for each indicator in this work ethic dimension ranges from $0.730-0.857$. Meanwhile, the most important thing that is perceived in the Non-Commander officer is "carrying out the profession with full integrity". The mean value on the dimension of work ethics ranges from 3.69 to 4.10 , with an average value of 3.87. The mean value shows that the dimension of work ethics is categorized as good. 
The dimension of professional commitment tends to be reflected by indicators of "have a high dedication as a non-commissioned soldier". The factor weight value for each indicator on this physical evidence dimension ranges from 0.813 to 0.913 . While the most important thing perceived in the field by respondents is "uphold the honor as a non-commissioned soldier". The mean value for each indicator on the dimension of professional commitment ranges from 3.93 to 4.22 , with an average value of 4.07 . The mean value shows that the perception of the dimension of professional commitment is categorized as very good.

The dimension of professional identification tends to be reflected by indicators of "maintain a good level of warrior idealism". The factor weight value for each indicator on this dimension ranges from 0.693 to 0.883 . Meanwhile, the most important thing perceived in the field by respondents is "maintain a good level of warrior idealism". The mean value for each indicator on the dimension of professional commitment ranges from 4.00 to 4.15 , with an average value of 4.08 . The mean value shows that the perception of the dimension of professional identification is categorized as very good.

Of the five dimensions of military professionalism, the highest value is on the dimensions of "Professional identification". While at the variable construct level, the average value of Military Professionalism was found to be 4.97, which means that the value is included in the very good category. The range of average values for each dimension ranges from 3.849 to 4.080 . The results show that empirically the construct of military professionalism can be well confirmed for the discriminant validity criteria and from the factor weight value for each indicator observed in this study.

Table 3. Mean and Coefficient of Weight Factors Value for Dimension of Military Professionalism

\begin{tabular}{|l|c|c|c|c|}
\hline \multicolumn{1}{|c|}{ Construct } & Mean & $\begin{array}{c}\text { Loading } \\
\text { Factor }\end{array}$ & t-statistic & Remarks \\
\hline Autonomy & 3.849 & -0.025 & 0.1356 & Insignificant \\
\hline $\begin{array}{l}\text { Maintenance of collegial } \\
\text { standards }\end{array}$ & 4.022 & 0.740 & 10.1684 & Sign \\
\hline Work ethics & 3.878 & 0.023 & 0.1330 & Insignificant \\
\hline Professional Commitment & 4.076 & 0.791 & 13.6551 & Sign \\
\hline Professional identification & 4.080 & 0.838 & 16.2864 & Sign \\
\hline
\end{tabular}

Source: Factor Analysis Output

It is revealed that the outer loading value as the result of the estimation of the research model shows that not all dimensions of military professionalism have outer loading of $>0.60$, or with the t-statistic value, criteria found to be still below the value of 1.96 . Some of the indicators which were found to have a factor weight value below the criteria and not significant are autonomy and ethics.

Based on Table 3 above, it can be seen the value of the factor weight coefficient on each dimension of military professionalism that exceeds the standard value of 1.96 is declared significant and vice versa. The variable of military professionalism can be reflected by three important constructs, namely maintenance of collegial standards, professional commitment, and professional identification. These three indicators in the loading factor value have shown significant criteria ( $\mathrm{t}$-statistic value $>1.96$ ), with a very high range factor weight values from 0.740 to 0.838 . Of the five dimensions, it is figured out that the professional identification 
dimension has the highest factor weight value if compared to other dimensions. The dimension with the lowest factor weight value is the maintenance of collegial standards in military professionalism.

The dimension of autonomy cannot reflect military professionalism. Interestingly, the Indonesian Army Forces do not consider that autonomy in their work as something that can reflect professionalism in the workplace. However, the reality is that there are many levels of autonomous capabilities and to integrate these into a military force is a complex phenomenon. According to Huntington, it has been stated that political leaders of a country will maintain a level of military professionalism by granting military autonomy within the scope of their actions, for example in a military operation. This military "objective control" provides for the healthiest civil-military relations while maintaining military combat effectiveness.

Dimensions of work ethics cannot reflect military professionalism, this is because in their assignments the Indonesian Army Forces tend not to be able to consider ethical concepts to be upheld when this is related to efforts to maintain national security stability. In a war situation, of course, no longer talk about ethical concepts or not, but how to win the competition and beat the more important opponent. As traditional military ethics has emphasized an approach to just war thinking, how members of the armed forces have behaved in past and present conflicts raise questions on the correct ethical behavior of soldiers.

\section{Conclusion}

The results of this study indicate that the military professionalism construct cannot be applied to all of its dimensions. Two of the five dimensions of military professionalism were found to be insignificant in reflecting professionalism for army soldiers. Of the 150 NonCommander Officers (CFOs) of the Indonesian Army who work in Battalion Arhanud $2 / \mathrm{ABW} / 2$, Kostrad Malang assesses that the most important military professionalism is reflected by professional identification, professional commitment, and maintenance of collegial standards. Meanwhile, Autonomy and Work ethics do not reflect military professionalism.

Furthermore, it is important to ask ourselves what we are going to measure when we claim to measure professionalism. The professionalism rating scale item measures beliefs about professionalism. The question proposed is whether beliefs about professionalism are synonymous with professionalism or beliefs drive behavior. However, the actual behavior shown depends not only on beliefs but also on other factors, such as the environment and soldier competence.

Future research related to the insignificant result of the dimension Autonomy and work ethic needs to be conducted in other Batallion, not only in East Java but Also throughout Java Island.

\section{References}

[1] Butler, A., \& Budgell, G. (2015). Study on army professionalism (Defence Research and Development Report).

[2] Djuyandi, Y. (2007). Membangun Demokrasi Melalui Profesionalisme Tentara Nasional Indonesia. Reformasi Sektor Keamanan Indonesia 2007, 3(9), 512-522.

[3] Evetts, J. (2013). Professionalism: Value and ideology. Current Sociology, 61(5-6), 778-796. https://doi.org/10.1177/0011392113479316

[4] Freidson, E. (1999). Theory of professionalism: Method and substance. International Review of Sociology, 9(1), 117-129. https://doi.org/10.1080/03906701.1999.9971301 
[5] Gates, J. M. (1985). The "New" Military Professionalism. Armed Forces and Society, 11(3), 427436.

[6] Hall, R. H. (1968). Professionalization and Bureaucratization. American Sociological Review, 33(1), 92-104. https://doi.org/10.1126/science.135.3503.554

[7] Harries-Jenkins, G. (1990). The concept of military professionalism. Defense Analysis, 6(2), 117130.

[8] Haywood-Farmer, J., \& Stuart, F. I. (1990). An instrument to measure the 'Degree of professionalism' In a professional service. The Service Industries Journal, 10(2), 336-347. https://doi.org/10.1080/02642069000000034

[9] Holmberg, A., \& Alvinius, A. (2019). How pressure for change challenge military organizational characteristics. Defence Studies, 19(2), 130-148. https://doi.org/10.1080/14702436.2019.1575698

[10] Kasenda, G. I. F., Djati, S. P., \& Suprapto, S. (2020). Analisis Profesionalisme Prajurit TNI Angkatan Laut Dalam Mendukung Pertahanan Negara di Komando Armada I. Jurnal Manajemen Pertahanan, 6(2), 108-127.

[11] Kristiadi, J. (2014). Profesionalisme TNI di tengah Transisi Politik. Antropologi Indonesia, 0(64), 19-40. https://doi.org/10.7454/ai.v0i64.3407

[12] Ma'arif, S. (2015). Prajurit Profesional-Patriot: Menuju TNI Profesional pada Era Reformasi. MASYARAKAT: Jurnal Sosiologi, 19(2), 257-286. https://doi.org/10.7454/mjs.v19i2.4704

[13] Norheim-Martinsen, P. M. (2016). New sources of military change - armed forces as normal organizations. Defence Studies, 16(3), 312-326. https://doi.org/10.1080/14702436.2016.1195234

[14] Paterson, P. (2019). Measuring Military Professionalism in Partner Nations: Guidance for Security Assistance Officials. Journal of Military Ethics, 18(2), 145-163. https://doi.org/10.1080/15027570.2019.1638461

[15] Plant, J. F., Stalebrink, O. J., \& Vasavada, T. (2010). Public values, public official associations, and professionalism: A cross-national analysis. American Review of Public Administration, 40(6), 722 741. https://doi.org/10.1177/0275074009360821

[16] Sejjaaka, S. K., \& Kaawaase, T. K. (2014). Professionalism, rewards, job satisfaction and organizational commitment amongst accounting professionals in Uganda. Journal of Accounting in Emerging Economies, 4(2), 134-157. https://doi.org/10.1108/jaee-01-2012-0003

[17] Tanjung, A. J., Imran, M. A., Dalimunthe, W. S., Lubis, S. H., \& Syahputra, U. (2020). Pengaruh Profesionalisme, Karakteristik Pekerjaan Dan Komitmen Organisasi Terhadap Kinerja Pegawai Di Dinas Sosial Kabupaten Labuhanbatu Utara. Jurnal Riset Akuntansi Multiparadigma (JRAM), 7(2),

[18] 179-187. https://jurnal.uisu.ac.id/index.php/JRAM/article/view/3375

Tiara, I. U. (2013). Profesionalisme Militer di Korem 032 Wirabraja Sumatera Barat. Tingkap, IX(2), $141-155$. 